\title{
Cross-culture Education and Moral Education in English Teaching
}

\author{
Jie Wang \\ Department of College English Teaching, Shandong University of Technology \\ Zhang Zhou Road, Zhangdian District, Zibo 255049, China \\ Tel: 86-533-278-8729 E-mail: wangjie560703@sina.com
}

\begin{abstract}
With the development of modern culture, it is meaningful for our Chinese teachers to develop and improve moral education and way of thinking in English cross-culture education, which will enhance university students' ability in distinguishing choosing western culture during their learning.
\end{abstract}

Keywords: Language, Culture, Cross-culture education, Moral education

In China, people pay much more attention to cross-culture education in English teaching. But as far as the recent study result is concerned, most researchers mainly discuss this topic with the views of improving quality of education and increasing students' capability in language using. Language is the basis of culture, which can be reflected by language. At the same time, language is the significant component of culture.

Language is the most prominent symbol of a national culture; it reflects one nation's daily life and includes one nation's way of thinking. In a developing country like China, learning English occupies too much time for students, as a result, the content of western culture is accepted by Chinese students unconsciously and affects students' view toward world, life and social value. Thus, we need to choose English as a means o begin cross-culture education. By analyzing the differences between the West and the East and comparing the positive parts and negative parts, we teachers can guide students to accept the essence of western culture and is card the dross. All these above are important to students' moral education. Before we introduce cultural education into English teaching and carry on moral education by cultural comparison, we should firstly grasp the differences in tradition between the West and the East.

There are mainly three different aspects between China and the West. First is the relation between human being and nature. In China, from ancient time, we Chinese people pay stress on 'the unity of God and human being. Its main idea is to emphasize the harmony between human being and nature; the western culture underline the conflict between human being and nature, whose core is to emphasize the human beings' ability to conquer nature. Second is the relation between human being and society. Chinese culture pays more attention to social values and try to hold the unity of individuals and society; western culture highlights the influence from individuals. Its recognition to individuals' influence is superior to that from society. Third is the difference in way of thinking. From ancient time, Chinese people form the habit of looking at this world systemically, logic thinking, however, plays the key role in western culture.

Choosing culture education in English teaching and putting moral education into teaching processes is based on analyze about cultural phenomenon, after this we can define cultural content of all kinds of cultural phenomena. And then discuss differences between the west and the east and get the positive and the negative. From this students can choose the positive parts and practice it. Before practice, teachers need to do moral investigation about cultural to students; carry on cultural training to teachers; choose right angles and methods to begin cultural introduction Before we start to teach students, we need to do investigation about students thinking about culture; improve teachers' cultural level and choose right way to carry on.

\section{The purpose for doing a moral investigation in culture to university students is to get to know the students' concepts and opinions about our traditional culture and western culture.}

For most students were born in 1980s the time for our country to carry out the policy of reform and opening. Also, most students major in scientific subjects or art subjects in high school and all their exams are for college entrance exam. Such a condition makes us think it is necessary to know how much advanced traditional culture still exist among them and how much they know about western culture and how they think about western culture. The university students' quality in culture not only is related to formal education, but also has relation to family education, living conditions and students' interests. All above is needed to be investigated and analyzed seriously.

\section{Improve teachers' level in culture.}

In our teaching activities, teachers play an important role and whether we will have the successful cross-culture 
education is greatly determined by teachers' synthetic level. With many years contact with English, most English teachers have known western culture for a great deal of. But on the other hand, still some of hem don't understand and grasp Chinese traditional culture systematically. Because of this, we need to cultivate English teachers about traditional culture. By reading classic works, taking part in speeches held by experts holding some seminars, we can get improvement in teachers' cultural level.

\section{The means to complete cultural introduction.}

We know that language learning is the most important in English teaching. For Chinese students, the major purpose to learn English is to communicate in English. When we finish this target, we can start the second stage, it is to put moral education on the basis of cross-culture education into effect. The second step is hard to fulfill, for it needs us to consider at what time and how to introduce western culture and compare western culture and Chinese culture. In the light of relation of language and culture, we can introduce the cultural comparison and discuss it with students with teaching regulations and sequence. Many experts have got some research results and with these results we can introduce culture discussion into our English teaching with three steps. Step one: introduce cultural discussion into English teaching with the learning of basic information. On this stage, we should analyze the cultural elements and genes with the learning of language, vocabulary, grammar and sentences. Meanwhile, lots of key elements related to language about culture between the east and the west should also be considered. The purpose to do this is to eliminate understanding barriers for cultural difference. On the other hand, it can reveal the cultural connection.

The cultural introduction in second stage becomes more systematically. On this stage, the cultural discussion is chiefly carried out with the explanation of text. The steps are as followings: (1) Get a cultural scheme which can cover the related text and list related cultural items which should be talked about with students. The cultural information is talked over with students while language structure is taught. (2) Get a cultural summary which includes the whole content of the textbook with all the texts in that book. Teachers can explain the cultural content before the class or after class. The boundary of 'culture items' is hard to be agreed on and experts and teachers hold different opinions about this. Some believe culture can be divided into several concrete items according to certain structures and standards, such as 'dining, accommodation, greeting, introduction, invitation, declination and so on'. The cultural introduction with division like this can be used to analyze and explain cultural phenomena for a particular behavior. Also, we can reveal cultural differences between the West and the East in daily lives. After overcoming the language barriers in communication, we will indulge into discussion about values, thinking method and many other deeper cultural topics and accordingly improve students' moral idea. The third stage is to talk about history and philosophy with view of culture. The key in this stage pays more attention to generality and cultural origin. The best way to deal with such topics is to hold optional courses and lectures on some special topics. The necessity to fulfill the target on this stage must construct a theoretical system which can reflect one nation's literature and characters. For one thing, this system must reflect historical origin of a nation and summarize the basic characters of a nation as well. Meanwhile, we must realize cultural differences among different nations with this system. From the philosophical angle, this theoretical system should include 'the relation between human being and nature', 'the relation between human being and society' and 'thinking method' and so forth. All these cultural introductions are jointed systematically and scientifically. In practice, we should introduce cultural items into students' learning in the light of different levels. The cultural introduction in first level fits for our basic English teaching. Those junior non-English major students and some fresh learners are within this scope; students who major in English in colleges and universities and senior non-English students are able to accept cultural discussion in the second and the third level.

\section{Try to make teaching means and methods colorful.}

As far as cultural introduction in teaching is concerned, students need to be stimulated. During the course of teaching in classroom, setting some sorts of cultural atmosphere and organizing many kinds of simulated condition are needed. We, for example, can get a movie or TV program to play, still, we can do a cultural analysis about some important historical events and many social items; analyze thinking method and values about western countries by a great deal of works (literature, painting and sculptures). Also, students can discuss those interesting cultural topics, and analyze cultural differences related to language actively, thus students' ability in judging and choosing culture will be raised.

\section{Do practice out of classroom as much as possible.}

Activities play an important role in education, and language learning also needs practice. To the same reason, moral education cannot exist without practice. Students will have deeper understanding about western culture and differences between the West and the East by doing colorful activities and conducting language communication. When we do some activities related to cultural education, the following may be helpful: (1) hold seminars. Some topics such as 'language and culture', 'American culture' in order to cultivate the students' ability in consulting materials independently, coming up questions, thinking about questions from different angles and analyzing and solving problems. (2) Ideological communication. Students should be organized on purpose to interview foreign teachers and students, have seminar with them, through which the students will acquire more cultural information. (3) The students should be encouraged to 
participate in extra-curricular activities, such as English corner, English speech contests and so forth. Thus their cross-cultural ability will be greatly tested and improved.

\section{References}

Jiang, Ningpeng. (1994). The Chinese Troditional Culture and Westen Culture. Journal of Jinzhou University (Social Science Edition), (2)

Lin, Ruchang. (1996). Three Levels of The Foreign Language Teaching And Leading of The Culture, Journal of The Foreign Language World, (4) 